\title{
La República en las trincheras. Iconografía republicana en Cabichuí y El Centinela (1867-1868)
}

\section{The Republic in the trenches. Republican iconography in Cabichuí and El Centinela (1867-1868)}

\author{
Matías Borba Eguren \\ Universidad de la República \\ Uruguay
}

DOI: https://doi.org/10.25032/crh.v7i12.4

Recibido: $30 / 3 / 2021$

Aceptado: $23 / 5 / 2021$

Resumen. Durante el conflicto de la Triple Alianza (1864-1870), el Gobierno paraguayo apeló a la prensa satírica como propaganda en contra de los Aliados, e instrumento para elevar la moral de la tropa. Sus páginas se caracterizaron, principalmente, por su discurso satírico y por la inclusión de xilograbados. El presente artículo pretende observar dos de estos periódicos de trinchera: Cabichuí (1867-1868) y El Centinela (1867-1868). Se analizará cómo es representado el concepto República en las ilustraciones relevadas, así como los artículos que las acompañan. Desde una perspectiva de la historia visual de los conceptos, se buscarán establecer cercanías y diferencias entre ambas publicaciones.

Palabras claves: Iconografía, República, prensa de trincheras

\begin{abstract}
During the Triple Alliance conflict (1864-1870), the Paraguayan government appealed to the satirical press as propaganda against the Allies, and as an instrument to raise troop morale. The government propaganda was characterized mainly by his satirical speech and the inclusion of woodcut engravings. This article aims to observe two of these trench newspapers: Cabichuí (1867-1868) and El Centinela (1867-1868). We will analyze how the concept "Republic" is represented in the illustrations, as well as the articles associated with them. From a perspective of the visual history of the concepts, we will seek to establish closeness and differences between both publications.
\end{abstract}

Keywords: Iconography, Republic, trench press 


\section{Introducción}

La Guerra de la Triple Alianza fue uno de los enfrentamientos más importantes en la Cuenca del Río de la Plata en el siglo XIX. En sus prolegómenos, así como en su desarrollo, la prensa fue un elemento clave para definir posiciones, criticar actitudes y esgrimir argumentos justificativos de cada bando. El enfrentamiento no se produjo solamente en el campo de batalla, sino que fue también una «guerra en el papel» (Maestri 2013) (Silveira 2017). En este sentido, los periódicos en el frente paraguayo son un ejemplo claro de este aspecto.

El Paraguay no tuvo una gran producción de prensa durante sus primeros cincuenta años de vida independiente. Esta siempre estuvo sujeta al control del Estado, ya sea por la censura, o por la impresión de periódicos oficiales. Durante el gobierno de Gaspar Rodríguez de Francia (1814-1840) su existencia fue mínima, limitándose a prensa extranjera que pudiera entrar de manera clandestina. Bajo el gobierno de Carlos Antonio López (1844-1862), el Paraguay buscó modernizarse y se propició el desarrollo de los primeros periódicos. Surge así El Paraguayo Independiente (1845-1852) y el Semanario de Avisos y Conocimientos Útiles. Periódico semanal dedicado a los negociantes, labradores e industriales (1853). ${ }^{1}$ Ambos fueron impresos por el gobierno de López, y abrieron el camino para el surgimiento de otras publicaciones que, sin ser de propiedad del Estado, estuvieron bajo vigilancia y control de este (Caballero Campos y Ferreira Segovia 2006; Johansson 2017).

El carácter oficial de la prensa paraguaya continuó bajo el gobierno de Francisco Solano López, quien supo apelar a esta durante el conflicto. La guerra entre Paraguay y la Triple Alianza se llevó a cabo entre 1864 y 1870, insumiendo recursos económicos, naturales y humanos en un conflicto que se pensaba que se resolvería a corto plazo. Su desarrollo se dio casi totalmente en territorio paraguayo, culminando con la toma de Asunción en 1869, y la posterior cacería y muerte del Mariscal López, el 1. ${ }^{\circ}$ de marzo de 1870. A pesar de los avatares del conflicto, la prensa en Paraguay continuó funcionando bajo control del gobierno. En medio de los obstáculos que significó la guerra, la imprenta

\footnotetext{
${ }^{1}$ La publicación de El Paraguayo Independiente ocurrió en el marco de las tensiones entre López y Rosas, debido al no reconocimiento de la independencia paraguaya por parte del caudillo argentino. Este se enfocó en defender la independencia del Paraguay y lograr el reconocimiento del gobierno argentino. El temor ante las aspiraciones rosistas por reconstruir el viejo Virreinato del Río de la Plata hizo al Estado paraguayo invertir en un medio de prensa oficial que defendiera su posición. En 1852, cuando finalmente el gobierno argentino reconoce al Estado paraguayo como nación independiente, el periódico desaparece (Johansson 2017).
} 
del Estado publicó cuatro nuevos periódicos: El Centinela (1867-1868), Cabichuí (18671868), Cacique Lambaré o Lambaré (1867-1868), y Estrella (1869).

Estos se enfocaron en fungir como medios de propaganda de la causa paraguaya, destinada a un público distinto: la tropa. Explica María Lucrecia Johansson (2014, 2017), que ante la necesidad de lograr el apoyo de toda la población la publicación de estos periódicos trajo consigo innovaciones para la prensa del país. Así, «... la prensa de guerra se transformó con la inédita incorporación de textos escritos en lengua guaraní, la introducción de ilustraciones y la edición de periódicos autodenominados satíricos» (Johansson, 2017: 86). Su circulación en el frente de batalla tuvo una rápida aceptación, siendo un elemento cohesionador, así como de divertimento, de los soldados. En paralelo, fueron un medio de propaganda hacia el exterior, pues estos también eran conocidos por la tropa enemiga. Sin embargo, los obstáculos generados por el desgaste del conflicto impidieron que su tiraje durara más allá de un año.

Para el presente análisis, se trabajará con dos de estos periódicos en particular: el Cabichuí y El Centinela. Ambos se distinguieron por sus xilograbados alusivos al conflicto que acompañaban los textos. Johansson (2012, 2012b, 2014, 2016) señala que la función de «informar» sobre el enfrentamiento se vio atravesada por sus intenciones de regular conductas y modelar representaciones a través de la propaganda textual y visual, utilizando un discurso satírico contra el enemigo, a la vez de exaltar al Ejército paraguayo. ${ }^{2}$ La autora indica que se buscó por un lado «... afianzar la cohesión social, mediante la reducción, y más aún de la eliminación de las diferencias políticas e ideológicas y la consolidación de vínculos fundados en lo emocional, y por otro, imponer imágenes estereotipadas y negativas del enemigo como un reflejo opuesto de una imagen propia positiva» $(2014,90)$.

Estos presentan un discurso -textual y visual- donde se plantea el enfrentamiento del Paraguay como una defensa del sistema republicano frente al Imperio invasor y sus aliados. Brasil es colocado como el principal enemigo, contraponiendo su gobierno monárquico y esclavista, con los gobiernos republicanos del resto de los países rioplatenses (Caballero Campos y Ferreira Segovia 2006; Johansson 2012b, 2014). De esta manera, este trabajo se enfocará en la iconografía republicana de ambos periódicos. Tanto en el Cabichuí, como en El Centinela, la República del Paraguay es representada

\footnotetext{
2 Indica Johansson (2014) que la información publicada en estos periódicos se encontraba bajo estricto control de Francisco Solano López, señalando que «... una de las características principales de esa propaganda fue la desinformación y el silenciamiento» (110).
} 
en distintas situaciones y con distintos atributos, dando cuenta de una iconografía que encierra significados que dialogan con el contexto bélico.

Partiendo de los postulados W. J. T. Mitchell (2017), se entiende que analizar una imagen es cuestionarse qué es lo que esta quiere transmitir. Para esto, el autor indica que se debe responder en «términos de carencia», entendiendo que lo que la imagen representa no refiere a una realidad existente, sino a una anhelada. Cuando la imagen a analizar es la representación de un concepto político, es necesario observar la historicidad de su semántica. En esta conjugación entre imágenes y palabras, la contextualización y evolución del concepto político refiere no solo a su sentido, sino también a la representación iconográfica. Como señala Javier Fernández Sebastián (2014), estudiar los conceptos -y su iconografía - apela a comprender el uso que los agentes hacían de estos, en situaciones y contextos concretos. Usos que refieren a estrategias persuasivas, o a deseos de modificar/conservar su marco político y social. En esa dialéctica entre imágenes -reconocibles y producidas-, y experiencias vividas, es necesario mostrar las complejas relaciones de ida y de vuelta que ciertas representaciones, y ciertos discursos, guardan con un contexto histórico determinado.

Desde esta postura, se estudiarán las representaciones del concepto República en los xilograbados de los citados periódicos. Se analizará la iconografía utilizada, y su inserción en el discurso oficial de la propaganda paraguaya. Es menester señalar que existe una gran mayoría de representaciones republicanas en el Cabichuí, en comparación con El Centinela. Por esta razón, se prestará mayor atención al primero, para luego comparar las representaciones de ambos en torno algunos acontecimientos puntuales durante 1867. En este sentido, la incorporación de El Centinela en este análisis permite observar similitudes y disidencias en la iconografía utilizada para representar el concepto político en cuestión.

\section{Los periódicos de trinchera}

La prensa de trinchera o prensa de guerra posee elementos particulares que la convirtieron en un instrumento propagandístico, tanto para el público paraguayo como para el extranjero (Johansson 2014b, 2017). Si bien cada periódico publicado entre 1867 y 1869 tuvo sus características particulares, pueden señalarse algunos rasgos comunes.

En primer lugar, explican Herib Caballero Campos y Cayetano Ferreira Segovia (2006), que una de las innovaciones más interesantes de estos periódicos fue la inclusión de textos en guaraní. Señalan los autores que, en la tradición, el guaraní había sido 
confinado al espacio privado, siendo el español el utilizado en la esfera pública oficial. La incorporación de esta lengua significó la ampliación del público lector, así como su traspaso a la expresión escrita. Francisco Solano López impulsó este aspecto, pues vio en la lengua guaraní una forma efectiva de difundir la propaganda oficial a gran parte de la población. En paralelo, el uso de una lengua prácticamente desconocida para los aliados era una ventaja importante en el enfrentamiento.

Por otro lado, estos periódicos se caracterizaron por la inclusión de ilustraciones de corte satírico, pero también celebratorio. El uso de xilograbados, acompañados de textos explicativos o relacionados, fue un elemento distintivo. A través de estos, se buscó ridiculizar al enemigo y fortalecer la moral de la tropa (Johansson 2014). Su circulación en el frente de batalla permitió que no solo soldados paraguayos tomaran contacto con estas publicaciones. En distintas ocasiones, ante el avance aliado y la retirada de las fuerzas paraguayas, algunos números eran dejados atrás, llegando a manos enemigas las ilustraciones despectivas en su contra (Johansson 2017).

Como plantea Burke (2005), la representación del otro es siempre una representación de uno mismo. Es un distanciamiento del «yo» con el «otro», construyendo una identidad propia, distinta a la supuesta identidad alterna. La caricaturización del enemigo presentaba antecedentes en la región que pueden ser rastreados hasta principios del siglo XIX, en especial a partir de los procesos independentistas y en la conformación de los estados nacionales en el Río de la Plata. En el período a trabajar, es moneda corriente encontrar en la prensa argentina y brasilera publicaciones que se burlaban y criticaban a Francisco Solano López. ${ }^{3}$ La prensa paraguaya salió al cruce en esta guerra de desprestigio y apeló a recursos similares para ridiculizar a los aliados. Ambos bandos utilizaron las ilustraciones como forma de propaganda contra el otro, a través de la animalización, deformación y demonización, tanto de gobernantes como de oficiales y soldados. 4

Señala María Lucrecia Johansson (2014) que la representación del enemigo recurrió a la demonización, la animalización y la distinción de rasgos étnicos,

\footnotetext{
3 En este sentido, merece destacar el capítulo de Liliana Brezzo y María Victoria Baratta, «La imagen de Argentina en Paraguay» (2018), donde las autoras observan las «construcción del otro» entre Argentina y Paraguay, en una postura comparativa relevante y orientadora.

4 Cabe destacar el trabajo de Luc Capdevila, «O gênero da nação nas gravuras da imprensa de guerra paraguaia: Cabichuí e El Centinela, 1867-1868» (2007). El autor señala el uso de la «feminización» como forma de ridiculización del enemigo, entre los repertorios iconográficos de ambos periódicos. Este aspecto merece una mayor profundización - la cual no es posible desarrollar aquí- en la Historia de la prensa e iconografía satírica de la región.
} 
contraponiendo valoraciones negativas de los aliados a una exaltación positiva del Paraguay. En este sentido, el ejército de Brasil fue el blanco predilecto de la sátira de los grabados y los artículos, en particular por el componente esclavo que integró sus filas. Estos eran representados como monos o seres deformes que peleaban por temor -y no por defensa de su patria-. Señala María Silvina Sosa Vota (2017) que el uso de la figura del mono buscaba desprestigiar el Imperio brasilero, haciendo alusión a su vigente régimen. Brasil fue presentado como el principal enemigo del Paraguay, encarnando el primero la monarquía, la esclavitud y la barbarie, y el segundo la República, la libertad y la civilización.

Perla Valero (2017) expresa que esta oposición entre civilización y barbarie fue un argumento esgrimido por ambos bandos, con el fin de justificar la guerra y movilizar al pueblo. Explica dicha autora que, así como la guerra contra la tiranía de López fue presentada por los aliados como una cruzada civilizatoria, la lucha contra el Brasil fue presentada bajo el mismo argumento por el gobierno paraguayo. El Paraguay, como República, estaba llevando una lucha contra una monarquía esclavista, que había arrastrado a las Repúblicas oriental y argentina en sus aspiraciones imperiales. Tanto aliados como paraguayos se colocaron en el papel de defensores de la civilización.

Bajo esta argumentación, las ilustraciones que acompañaron la prensa de trincheras buscaron reforzar esta oposición entre República paraguaya e Imperio brasilero (Johansson 2014). Conceptos políticos como libertad, civilización, y república, fueron representados en oposición a esclavitud, barbarie, y monarquía. La inclusión de los xilograbados que personificaban o referían a estos valores e ideas, dan cuenta de una intención comunicativa por parte del Estado paraguayo. Johansson (2012) destaca el papel pedagógico que poseen estos periódicos; el uso de texto e iconografía en conjunto fue una herramienta capaz de difundir construcciones estereotipadas del enemigo, y reafirmar identidades movilizadoras para la guerra. La autora da cuenta de la circulación y recepción de estos periódicos; explica que, además de la distribución de los periódicos, las autoridades militares se encargaron de que el contenido de estos fuese asimilado. A través de la práctica de lectura pública y en voz alta, se ponía en conocimiento de la tropa su contenido (Johansson 2017 94).5

5 Johansson (2017) señala uno el grabado del 8 de agosto de 1867 , en $\mathrm{n}^{\circ}{ }^{\circ} 27$, donde se puede observar los
modos de lectura en los campamentos de batalla. Se representa a un sargento leyéndole el Cabichuí a sus
soldados. Estos últimos escuchan atentamente, a la vez que muestra gestos de aprobación y divertimento
por el contenido del periódico. Explica la autora que esta práctica de lectura pública fue una forma de 
La circulación y características de estas publicaciones indican una clara intención de transmitir un mensaje al soldado en el frente de batalla (Johansson 2014b). En este sentido, las ilustraciones fueron un vehículo fundamental para su transmisión y decodificación. En estas representaciones, distintos conceptos políticos fueron representados; entre ellos, la imagen de la República fue utilizada en diversas situaciones. En los próximos parágrafos se analizarán cómo el concepto político en cuestión se representa y con qué sentido esta representación se inserta en el discurso oficial.

\section{La República batallando: el Cabichuí y la causa del sistema republicano en Sudamérica}

El estudio de las representaciones iconográficas del concepto República en Paraguay presenta algunos antecedentes relevantes. Se destaca el artículo de José Emilio Burucúa y Fabian Alejandro Campagne, «Mitos y simbologías nacionales en los países del Cono Sur» (2003), en el cual los autores plantean una cronología de la evolución de los símbolos y mitos representativos de Argentina, Chile, Paraguay y Uruguay.

Para el caso paraguayo plantean que existe una diferencia en la construcción de simbologías, comparado con el resto de los países del Cono Sur. Los autores entienden que Paraguay se ciñó a un modelo europeo dejando de lado elementos relacionados al mundo americano prehispánico. En ese sentido, analizan el escudo nacional durante el gobierno de Francia, compuesto de una estrella de cinco puntas - metáfora de la ciudad de Asunción- entre ramas de olivo y palma. Tras la muerte del dictador, el Congreso General Extraordinario de 1842 mantuvo esta simbología, pero estableció otra para las medallas y las monedas, siguiendo la tradición europea: un león sentado bajo una pica y un gorro frigio, que aludía a la tradición revolucionaria francesa (439-440). En lo que respecta al himno y la bandera, esta característica se mantiene: alusiones a simbologías revolucionarias francesas, así como la permanencia de ciertos elementos de la tradición hispánica.

Ambos historiadores manifiestan que es un enigma la falta de metáforas sobre el mundo americano en esta simbología, a pesar de una cultura y tradición guaranítica

sociabilidad estimulada por el Gobierno paraguayo. Destaca la participación activa de los soldados en esta ilustración, al representarlos riendo y celebrando las palabras despectivas para con el enemigo. En este sentido, señala la intención del Cabichuí de «... imponer la convicción de que ningún paraguayo podía permanecer pasivo frente a los acontecimientos que sacudían al país, al mismo tiempo que buscaba validar al interés por conocer lo que la prensa difundía como una forma de expresar adhesión a la causa nacional» (96). 
fuerte. A modo de hipótesis, podría pensarse que el control ejercido por el Gobierno de Francia limitó la inclusión de representaciones que no fueran las emanadas por su concepción - y de sus allegados - de nación. ${ }^{6}$ Un gobierno concentrado en una persona, pero que se declaraba independiente de la corona española, bien pudo entender que el modelo europeo era el idóneo para generar la idea de independencia política, pero de continuidad de un determinado orden social. Bajo el gobierno de Carlos Antonio López, los autores sostienen que este modelo no varió demasiado a pesar de una política de mayor apertura. ${ }^{7}$ No obstante, pueden establecerse ciertos matices en referencia a lo americano.

Es menester señalar que los mencionados autores no observaron el período de la guerra contra los aliados. En este sentido, el trabajo de Michael Huner, «Toikove Ñane Retã! Republican Nationalism at the Battlefield Crossings of Print and Speech in Wartime Paraguay, 1867-1868» (2009), señala cómo el guaraní jugó un papel importante en la construcción de un discurso identitario en los periódicos de trincheras. Analiza expresiones guaraníes que se acercan al concepto de república, no como un sistema de gobierno, sino cercano a la idea de patria o nación. A su vez, el autor analiza distintas imágenes donde es representada la identidad republicana, la cuales serán analizadas en lo sucesivo. Huner deja de manifiesto cómo el elemento guaranítico se hace presente en la construcción y uso del concepto república.

En la misma sintonía, Johansson destaca, en sus múltiples artículos, la apelación no solo de la lengua, sino también de la flora, fauna y tradición guaranítica en los elementos representados en los grabados. A su vez, deja constancia de las tradiciones cristianas que pesan en el discurso visual y textual en los distintos periódicos publicados en el período de la guerra. ${ }^{8}$

Por otro lado, es menester señalar el trabajo de Roberto Amigo, en su artículo «La

\footnotetext{
${ }^{6}$ Los autores hacen referencia, en relación con la implementación de la bandera, que en 1814 «... al recibirse la noticia de que la Restauración de los Borbones había prohibido el uso de la tricolor revolucionaria en Francia y resuelto volver al estandarte blanco de La dinastía, el doctor Francia se declaró heredero de los colores del pabellón revolucionario francés debido a las resonancias de su apellido y a su confesada admiración por la persona de Bonaparte. A partir de entonces, las banderas exhibieron muchas veces franjas verticales sin que desapareciese la disposición horizontal. Dos años después de la muerte del dictador, en 1842, el congreso general extraordinario se pronunció por la última alternativa» (443).

7 Sin embargo, señalan que fue en el mandato del primer López cuando se comienzan a establecer fiestas cívicas con mayor frecuencia, algo casi inexistente durante el gobierno de Francia.

${ }^{8}$ La autora (2012) señala el ejemplo del cambio de nombre de Cacique Lambaré a Lambaré, dejando ver no solo el diálogo entre tradiciones guaraníticas y cristianas, sino también el intercambio entre la citada publicación y el Cabichuí (130-135).
} 
alegoría republicana en las trincheras. Una introducción a Cabichuí» (2016). El autor señala innovaciones en la construcción de imaginarios nacionales, particularmente la figura republicana en el Cabichuí. Da cuenta que se recurre a una simbología con mayores referencias al elemento americano, pero sin apartarse del modelo europeo. Las personificaciones del Paraguay en estos periódicos siguen el modelo francés de Marianne, apelando a una figura femenina, ${ }^{9}$ muchas veces acompañada de un gorro frigio. Este último en ciertos casos es colocado en solitario, dando a entender la alusión a la República del Paraguay, unida a otras representaciones. Por otro lado, estas alusiones al Paraguay están acompañadas con frecuencia por la figura del León, como representación del pueblo y su valor, aspecto también señalado por Johansson. Finalmente, la República paraguaya es colocada como equivalente a conceptos como patria o nación, en sintonía con lo descripto por Huner. Como se dijo antes, el uso del vocablo República en los distintos textos que acompañan las imágenes refiere a una clara intención de distanciarse del régimen monárquico del Imperio brasilero.

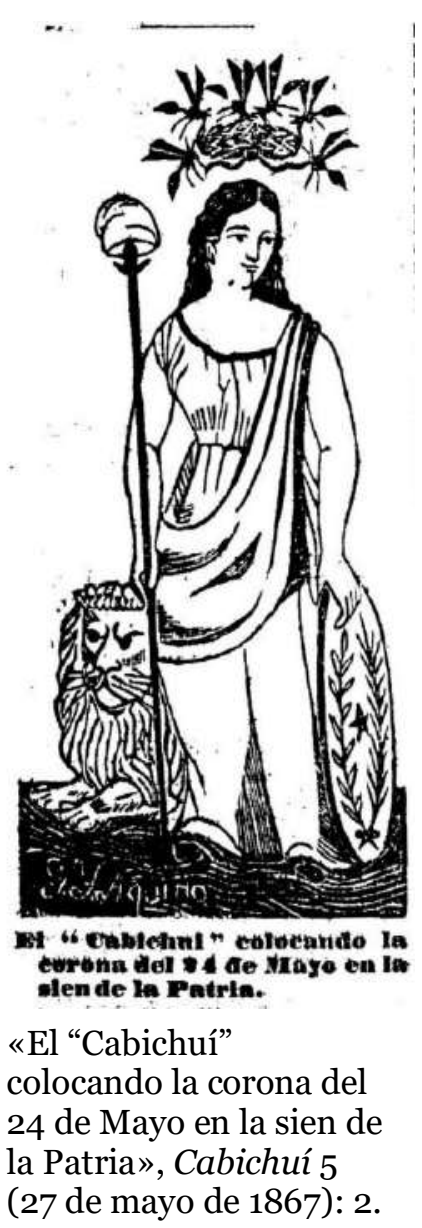

Roberto Amigo (2016) señala que la iconografía presente en el Cabichuí tiene una clara inspiración europea; este aspecto tiene mayor peso en el caso de El Centinela, donde aparecen también elementos del clasicismo. Sin embargo, existen ciertas referencias a lo americano en estas ilustraciones, las cuales no aluden de manera directa al mundo indígena, sino a una idea de América del Sur unida bajo el régimen republicano. Esto no anula la presencia de la lengua y tradiciones guaraníticas señaladas.

Por ejemplo, la ilustración publicada el 27 de mayo de 1867, en el número 5 del Cabichuí, resulta ilustrativa al respecto. Como se observa, la representación del propio Cabichuí - las avispas de color negro- cargan una corona de laureles y la colocan en la cabeza de la patria. Esta es representada por una figura femenina, portando el escudo nacional, y una lanza en cuyo final se encuentra un gorro frigio. A su lado, descansa el león, como representación del pueblo, y

\footnotetext{
9 Ariadna Islas y Ernesto Beretta (2019) señalan, para el caso de Uruguay, que el modelo europeo fue apropiado en la región, pero modificado en su fisonomía. Los autores señalan cómo la incorporación de elementos criollos, desde las cabelleras negras hasta la vestimenta, marcan una iconografía republicana propia de la región.
} 
de su valor. La ilustración hace referencia al aniversario de la batalla de Tuyutí, donde el ejército paraguayo llevó a cabo una gran ofensiva contra el campamento aliado, el 24 de mayo de 1867. Señala que el Cabichuí, quien tempranamente «...se afanara en tejer la inaccesible corona de laureles para ornar la nítida sien de la Virgen de América», ${ }^{10}$ hoy es quien la coloca. Culmina explicando los elementos que componen la imagen:

Es una pura ofrenda consagrada a los principios salvadores de libertad y de la democracia, de que ella responde contra cualquier enemigo, apoyada en el escudo de paz y justicia, y en la soberana magestad de su Independencia nacional, resuelta siempre a vencer o morir antes que someterse.

Ella enarbola a la faz del mundo el gorro triunfal, y a su sombra se ostenta radiante de gloria y heroísmo, haciéndose digna de que el universo la admire, y la aclame al par de nosotros, diciendo, iViva la República del Paraguay!11

Se apela al modelo europeo ya descripto, pero se añade la presencia del propio Cabichuí colocando la corona, entrelazando un elemento autóctono con una imagen que aspira ser universal. Es un elemento americano que corresponde a la fauna paraguaya y que contextualiza una alegoría republicana de inspiración europea.

No obstante, existe otra forma de referirse a lo americano que se relaciona con el concepto de República. En el número 9, del día 10 de junio de 1867, el Cabichuí publica un artículo y su correspondiente ilustración con el título «El Paraguay: la triple alianza ante la América democrática», en el que se da cuenta del significado de la lucha, denunciando el «escándalo» que significa la Triple Alianza para el mundo civilizado. Expresa que el Paraguay está llevando una lucha en la defensa de la «América democrática», ante el avance del Imperio de Brasil y sus ambiciones expansionistas. Cuestiona el papel de los gobernantes de Argentina y Uruguay, a quienes señala como «podenco» - Mitre- y como «burro de carga» -Flores-; ambos son presentados como traidores a sus repúblicas, a las cuales han empujado a una alianza con una monarquía en contra de una República hermana.

La imagen que acompaña el texto muestra a la República del Paraguay con una corona de laurel atacando, junto al León, a Flores y a Mitre. Estos últimos llevan encadenadas a sus respectivas repúblicas: la República uruguaya se presenta escuálida y desnutrida, mientras la argentina se encuentra con los ojos vendados. Detrás de las cadenas, dirigiendo desde la retaguardia, se representa a Pedro II. Finalmente, aparece América del Sur representada como una madre que carga con siete hijas en su rebozo,

10 «El «abichuí colocando la corona del 24 de Mayo en la sien de la Patria», Cabichuí 5 (27 de mayo de 1867): 2.

${ }^{11}$ Ídem. 
observando la lucha.

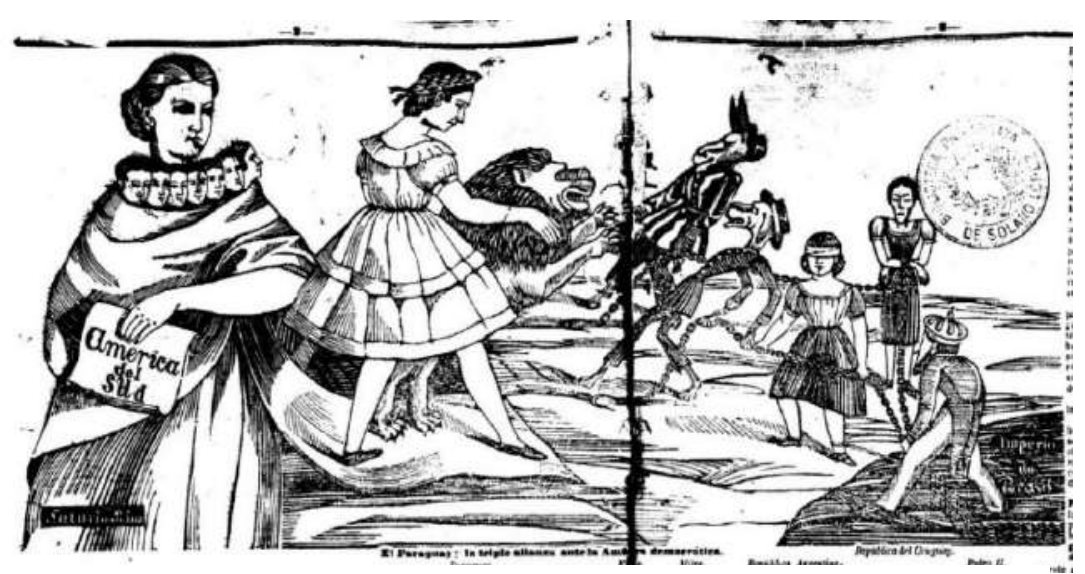

Resulta interesante cómo dialoga el artículo con la ilustración que lo acompaña. A lo largo de los distintos párrafos, expresa que la posición paraguaya es la defensa de una América del Sur caracterizada por el

«El Paraguay: la triple alianza ante la América democrática», Cabichuí 9 (10 de junio de 1867): 2-3. régimen republicano. En oposición, el Imperio de Brasil está poniendo en peligro esa América republicana -y «democrática»-, ${ }^{12}$ al punto de poner a «dos de sus hijas» contra su hermana paraguaya. En este sentido, el concepto de República es reivindicado y representado como sistema de gobierno opuesto a la Monarquía. El enemigo imperial -y quienes lo siguen- son representados como opresores de las Repúblicas oriental y argentina. Del otro lado, la República paraguaya y su pueblo valeroso, encarnado en el león (Johansson, 2014) - se colocan como la defensora del sistema de gobierno que une a todo el continente. El propio artículo brinda la explicación de la ilustración de la siguiente forma:

\begin{abstract}
Allí tenéis la vigorosa República Paraguaya ceñida en su frente con los laureles que ha recogido en los campos de batalla, firme en su defensa bajo el amparo del valor, la abnegación, el patriotismo y la unidad de todos sus hijos. Ante la imponente actitud del león, el asno Flores y el podenco Mitre a quienes el Brasil ha mandado por delante, medroso y asustados retroceden. El Imperio maneja las cadenas con que ha conseguido ya maniatar a la República del Uruguay, desangrada, débil, escuálida y sometida, y esa misma cadena es la que el traidor Flores, el burro de carga de Brasil, arrastra por cuenta de este para enganchar al Paraguay. El podenco imperial acomete igualmente llevando en sus manos la cadena brasilera; pero magullada por las garras del león solo ladra a la presa codiciada lejos del peligro. No por eso hace descansar a la República Argentina que poniéndole una venda en sus ojos le hace tirar también la cadena del monarca macacuno, que se convierta en sus propias prisiones, porque no puede mover un paso sin la voluntad del Brasil que le tiene sujeta por las piernas.

La América está representada en la robusta joven que lleva en sus pañales siete Repúblicas; y que asiste a la lucha de tres de sus hijas. Está del lado del Paraguay, pero su actitud es pasiva en la gran contienda que tan vivamente le interesa, por que solo el Paraguay es la que está de por medio entre ella y los enemigos de la democracia. ${ }^{13}$
\end{abstract}

Esta extensa cita da cuenta de un sentido definido para esta imagen. No solo se

\footnotetext{
12 Es necesario destacar el uso del concepto de democracia junto al de República, sobre el cual la historiografía no ha trabajado en su total profundidad para el caso paraguayo. Esto merecería un estudio particular en torno a este concepto, que no se hará en este trabajo. Se podría arriesgar ciertas interpretaciones de este concepto de democracia para el Paraguay. En este sentido, el artículo de Gonzalo Capellán de Miguel (2013) resulta ilustrativo al respecto.
}

13 «El Paraguay: la triple alianza ante la América democrática», Cabichuí 9 (10 de junio de 1867): 2-3. 
denuncia la actitud tomada por las demás repúblicas americanas ante el conflicto, sino que también advierte el riesgo que significaría para todo el continente un triunfo del Imperio. Por esta razón, la causa paraguaya es la causa americana; ante la amenaza expansionista de Brasil, se presenta inentendible la pasividad de las demás naciones ante la guerra (Johansson 2014). Amigo (2016) señala el elemento europeo en los modelos alegóricos, pero destaca el sentimiento americanista que la reviste (2016, 24-25). De esta manera, el concepto de república -en tanto gobierno opuesto a la monarquía- es presentado como unión de la región.

Como señala Johansson (2012b), al colocar a la República del Paraguay como defensora del sistema republicano del continente, ante el «avance monárquico», define a su enemigo: el Imperio de Brasil. Sus acciones corrompen esa unidad republicana. Nuevamente, el Cabichuí ilustra este discurso cuando representa una escena de tortura a las Repúblicas oriental y argentina por parte del Emperador, Mitre y Flores. El 25 de julio de 1867, en el número 22, se publica la siguiente imagen.

Se observa a los gobernantes aliados armando una hoguera. El emperador le solicita a Mitre y a Flores que traigan más paja, para aumentar la cantidad de combustible. En lo alto de la estructura, y sobre un barril de pólvora, descansan las Repúblicas argentina y oriental. Ambas se muestran quietas, observando las acciones de los tres hombres. El artículo que acompaña la imagen explica más en detalle el sentido de la ilustración.

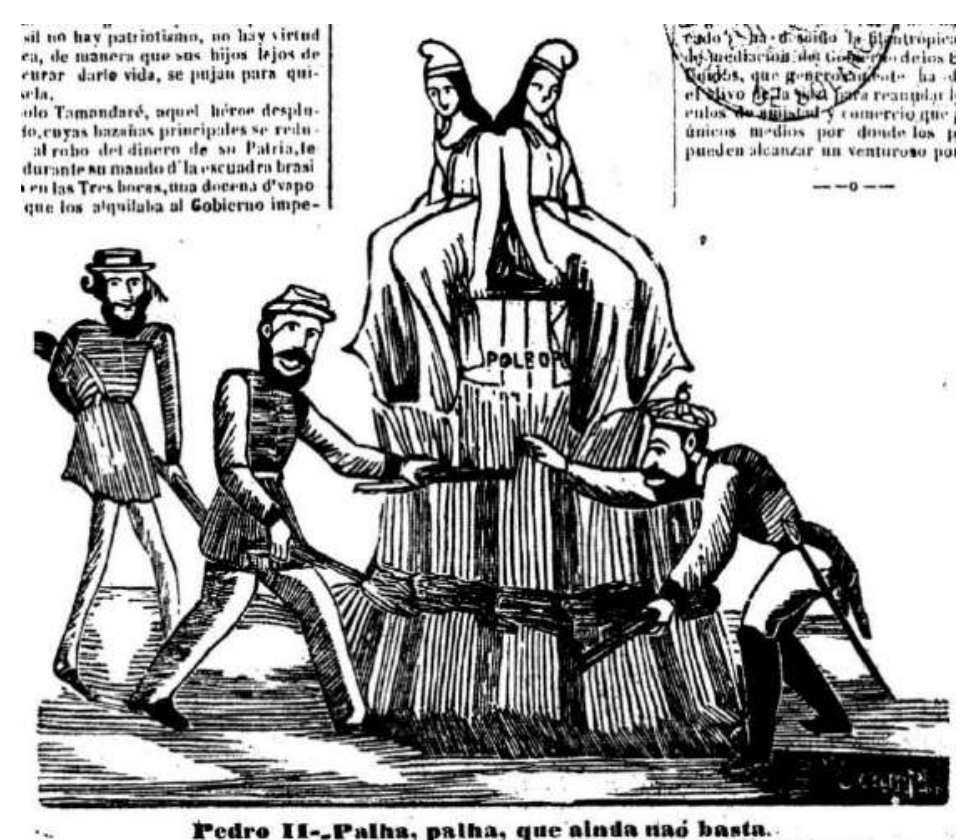

«Pedro II: Palha, palha, que ainda naó basta», Cabichuí 22 (25 de julio de 1867): 3

Bajo el título «Situación de las Repúblicas del Plata», ${ }^{14}$ el periódico hace un llamado al pueblo argentino y oriental para que reaccione ante la actitud de sus gobernantes. Expresa que las maniobras del monarca brasilero buscan «... destruir toda vuestra vitalidad para que ninguna resistencia podáis presentar a sus miras infernales el

14 «Situación de las Repúblicas del Plata», Cabichuí 22 (25 de julio de 1867): 3-4. 
día que se determine a poneros el cabestro en la garganta». ${ }^{15}$ Con ese objetivo Pedro II las ha arrastrado a la guerra, apoyado en la traición de Mitre y Flores. El texto continúa señalando a Brasil como el «enemigo común» y explica que el apoyo argentino y oriental a la causa paraguaya permitiría poner fin a la Monarquía, para que se retorne «...a la libertad republicana esa enorme fracción del mundo de Colón, que hoy vegeta en la más miserable esclavitud». ${ }^{16}$

La propaganda paraguaya insiste en esta idea: el conflicto de la Triple Alianza es señalado como estratagema de la Monarquía brasilera para concretar sus aspiraciones imperialistas. Argentina y Uruguay están siendo arrastradas a un conflicto que, tarde o temprano, tendrá consecuencia sobre su independencia. La alianza representa la desviación de una unidad americana basada en el sistema republicano. El Cabichuí ahonda en este discurso en el número 26, del 5 de agosto de 1867, apelando al vampirismo.

La ilustración muestra a la República Argentina y Oriental -en esta oportunidad sin su gorro frigio- siendo desangradas por sus respectivos mandatarios. En el centro de la imagen, el Emperador recolecta la sangre que cae de sus brazos, mientras solicita más y más. A través del artículo «Un monarca Caribe, y dos republicanos Vampiros»,17 reitera el

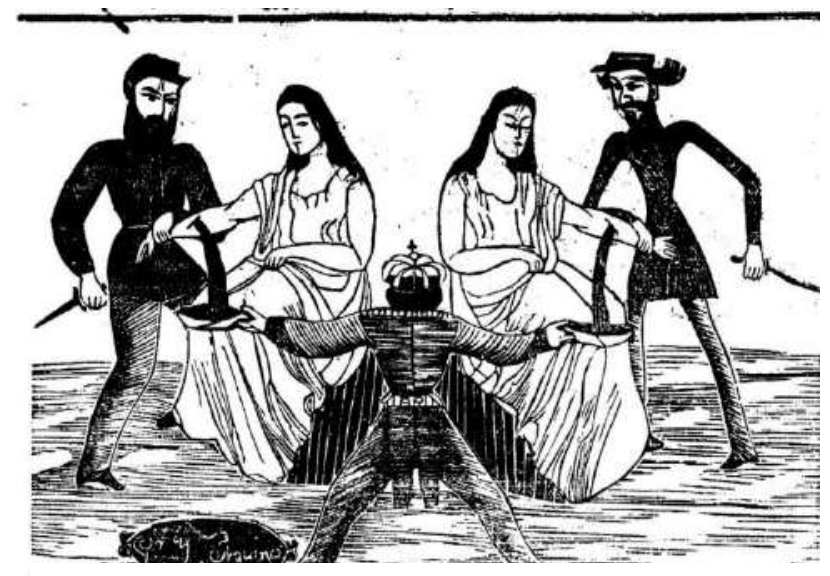

«El Emperador: abram bem esas veía, ainda ha sangue», Cabichuí 26 (5 de agosto de 1867): 2.

llamado al pueblo argentino y oriental. Señala que las aspiraciones del «Emperador macacuno» no resultan extrañas si se tiene en cuenta el carácter de «raza de los Caribes», de la cual proviene. ${ }^{18}$ Por otro lado, refiere a Mitre y Flores, caracterizándolos de vampiros:

Y ¿̇quién que conozca la fatídica tradición de los Vampiros, que se levantaban cubiertos, en las sombras de la noche a chupar la sangre de sus hermanos y sus amigos hasta darles muerte, no

\footnotetext{
15 Ibídem, 3.

${ }^{16}$ Ibídem, 4.

17 «Un monarca Caribe, y dos republicanos Vampiros», Cabichuí 26 (5 de agosto de 1867): 2.

${ }^{18}$ Esta alusión se enmarca en la ridiculización del componente afrodescendiente del ejército brasilero $-\mathrm{y}$ su población en general-. En esta oportunidad, se hace alusión a la «raza de los Caribes», conocidos por practicar la antropofagia, en una metáfora macabra de las ambiciones del Imperio sobre los territorios del Plata. Esto parece relacionarse de forma más explícita con la ilustración, al representar a Pedro II recolectando la sangre de las Repúblicas Argentina y Oriental (Caballero Campos y Ferreira Segovia 2006; Johansson 2014).
} 
se espantará ante la realidad latente que Mitre y Flores representan en su conducta feroz y desnaturalizada, con respecto a las Repúblicas Argentina y Oriental, su patria, en su alianza con el Caribe Monarca?19

La tradición de los vampiros puede ser rastreada hasta tiempos de la Edad Media, cuya herencia es trasladada a América. En este sentido, Gabo Ferro señala que, si bien en el continente ya existían figuras de «bebedores de sangre», es a través de la conquista, y las prácticas religiosas implantadas, que la figura del vampiro arriba al nuevo mundo. En particular, en el Río de la Plata, esta llega a través de diversas fuentes dentro de las corrientes de la ilustración y el romanticismo $(2008,110)$. En este sentido, señala el autor el conocimiento y circulación de obras literarias, filosóficas e históricas -como las de Agustín Calmet, Feijoo, Voltaire, Goethe, Víctor Hugo, Rousseau, entre otras-, donde el tema del vampirismo estaba presente.

Entiende Ferro que el uso de la imagen del vampiro alude a distintas actitudes, características y condiciones de un ser que encarna la aberración de la naturaleza: a) imagen de barbarie e ignorancia; b) corrupción de la naturaleza y del orden; c) idea del chupasangre, como quien se aprovecha del pueblo, mientras él goza de lujos -por ejemplo, habitar en palacios-,y d), la infección de las masas, como el virus que corrompe a toda la sociedad (102-129).

Si bien el autor analiza la figura del vampiro para el caso del rosismo, esto puede ser extrapolado a las representaciones del Cabichuí. ${ }^{20}$ Tanto en el xilograbado, como en el texto que lo acompaña, pueden observarse las distintas concepciones que implica dicha figura. La idea de barbarie, por una guerra que está desangrando a dos repúblicas hermanas del Paraguay, no es solo referida por el adjetivo macacuno atribuido a Pedro II, sino también por las acciones de Mitre y Flores. Este conflicto es también una corrupción a la naturaleza y al orden republicano, que separa a Argentina y a Uruguay del Paraguay, y los une a la monarquía brasilera. Los gobernantes son quienes extraen la sangre a sus repúblicas, para beneficiarse de su alianza con el emperador; esta alianza es una «conducta feroz y desnaturalizada» de Mitre y Flores para con sus Repúblicas, «chupándole la sangre a sus hermanos y sus amigos», para satisfacer al «emperador macacuno». Por último, se plantea la característica «infecciosa» de las actitudes «vampíricas» de los gobernantes argentino y oriental, advirtiendo al pueblo de ambas

\footnotetext{
19 «Un monarca Caribe...» 2.

${ }^{20}$ Liliana Brezzo y Victoria Baratta (2018) señalan este aspecto, destacando el uso de argumento similares de la prensa opositora al rosismo, en las publicaciones periódicas argentinas del período del conflicto contra Paraguay.
} 
repúblicas:

iAh, Argentinos y Orientales! El "Cabichuí" que estima vuestra suerte como deplora, con fraternal sentimiento, vuestras desgracias, ha querido esta vez presentaros el cuadro de la alianza de vuestros Vampiros Mitre y Flores con el Caribe monarca. Vedlo pues, y examinad vuestra obra, á la luz de vuestra conciencia [...]

iEs posible que dejeis de ser Argentinos y Orientales, y solo seais unos Vampiros como lo son vuestros gobernantes Mitre y Flores! iQuereis acaso proseguir avergonzado a la humanidad entera, y escarneciendo la tumba de vuestros padres; o volver por su gloria y la honra de los Argentinos y Orientales! Meditadlo, sobre el cuadro que teneis a la vista, y juzgad ante él la guerra que haceis a la República del Paraguay, y la causa que ella sostiene. ${ }^{21}$

El llamado por la causa paraguaya se presenta como advertencia a la vampirización de las Repúblicas del Plata. Las acciones de sus gobernantes están desangrándolas, contagiando la barbarie y corrompiendo la naturaleza republicana, a través de una alianza con la monarquía brasilera.

Esta construcción de un yo y de un otro establece dos bandos claros contrapuestos (Johansson 2012b). La Triple Alianza, como la representación de las aspiraciones imperiales, la barbarie y la corrupción de los gobernantes del Plata; por otro lado, el Paraguay como bastión republicano, quien representa la defensa de la unión americana bajo esta forma de gobierno. La ilustración publicada el 16 de diciembre de 1867, en su número 65, podría resumir esta idea.

Se observa a la República del Paraguay armada y sometiendo a un monstruo bajo sus pies. Este parece ser una hidra o una pitón, la cual hace alusión a la guerra y a las ambiciones de Brasil. Sobre la mencionada república se encuentra un globo representando «el mundo Sud-Americano» que descansa sobre la espalda de Paraguay, y se compone de representaciones de las Repúblicas de Argentina, Bolivia, Chile, Colombia, Ecuador, Nueva Granada, Panamá, Perú y Uruguay. El mensaje resulta bastante explícito: es el Paraguay quien está sosteniendo y defendiendo a la América republicana, ante la amenaza del monstruo imperialista de Brasil.

El texto que acompaña la imagen, «¿̇Qué somos y a dónde vamos?», ahonda en este discurso. Comienza

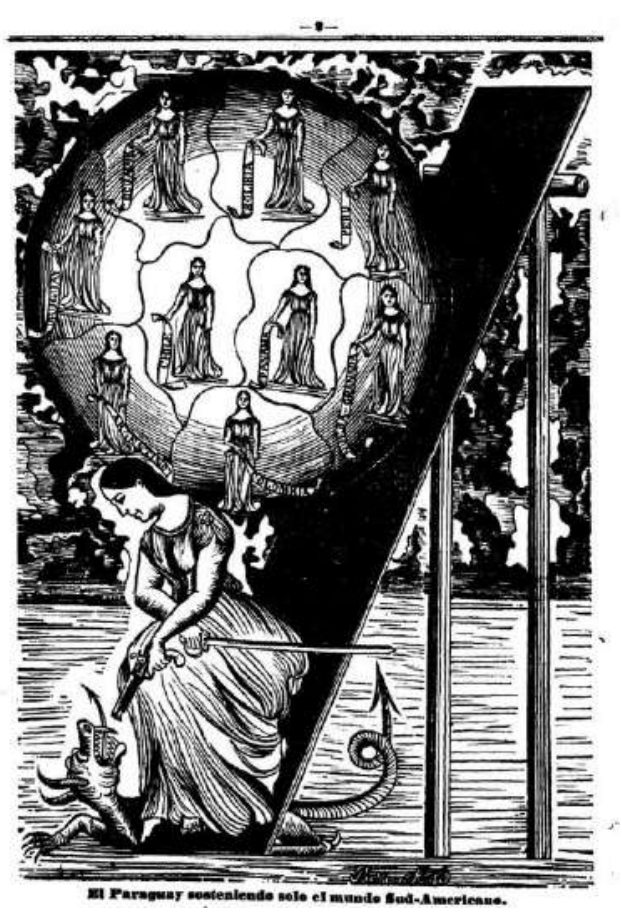

«El Paraguay sosteniendo solo el mundo Sud-Americano», Cabichuí 65 (16 de diciembre de 1867): 2.

21 «Un monarca Caribe...» 2. 
diciendo que la humanidad siempre se ha formulado esa pregunta, y los pueblos de América no son la excepción; estos respondieron ante esta interrogante cuando rompieron su vínculo con la Monarquía española, y «... se reunieron en torno del precioso árbol de la libertad, é hicieron resonar por todos los ámbitos de la tierra, como los otros pueblos, su voz de pueblos libres, soberanos e independientes».22 Sin embargo, el Cabichuí denuncia la indiferencia de los demás pueblos americanos ante la guerra que sostiene el Paraguay, argumentando que se han olvidado de preguntarse qué son y a donde van:

\begin{abstract}
¿Será posible que sola la República del Paraguay, sentada en el vasto continente de la libertad, es la que lucharía esgrimiendo la espada de la justicia, y las armas de la civilización contra el genio del mal, contra el monstruo Pitón de la nueva vida de los pueblos del hemisferio de Colón? [...]

Pero, iPueblos todos de América! Deteneos por un instante en vuestro tenebroso camino y decíos: ¿qué somos y a dónde vamos? y os encontrareis dando contra vosotros mismos, os encontrareis, dos de vosotros aliados directamente, y los demás, con su indiferencia como frias estatuas, indirectamente, a ese mismo monstruo devorador de nuestra existencia.

Y la República del Paraguay al repetirse en estos solemnes momentos lo que vosotros habéis omitido ¿qué somos y a dónde vamos? y con la conciencia de su causa, y de su fe incontrastable en ella, os dice: el monstruo está agonizante a mis pies; y con la protección de Dios, confirmaré con mi sangre sobre su espantoso féretro vuestra preciosa libertad!23
\end{abstract}

Se reafirma la contraposición de valores y conceptos (Huner 2009) (Johansson 2012b, 2014). Los aliados, con Brasil a la cabeza, son la barbarie, el despotismo, la Monarquía, el monstruo que amenaza al continente. El Paraguay, en cambio, encarna la civilización, la libertad, el sistema Republicano, y la causa de todo el continente americano. La idea del mundo Sud-Americano muestra cómo se construye, en este discurso propagandístico, la idea de una comunión republicana; la República es la forma de gobierno que América se ha dado y, ante la amenaza de una Monarquía, es el Paraguay quien le está haciendo frente.

En las representaciones analizadas se observa la intención de construir un discurso cohesionador (Johansson 2014b). El juego entre imágenes y texto presenta los argumentos del Gobierno paraguayo para sustentar, difundir y convencer a sus lectores. De esta manera, el Cabichuí delineó un discurso que apela al concepto de República -en sus distintas representaciones - para contraponer el Paraguay con el Imperio brasilero y sus aliados. En el mismo sentido, separa al enemigo aliado de la comunión republicana del continente sudamericano.

\footnotetext{
22 «¿QQué somos y a dónde vamos?», Cabichuí 65 (16 de diciembre de 1867): 3.

23 «¿Qué somos...» 3 .
} 


\section{La República y su Mariscal: diferencias entre Cabichuí y El Centinela}

Las anteriores ilustraciones analizadas se enfocan en la representación del concepto República. En lo que refiere a la República paraguaya, esta ocupa una

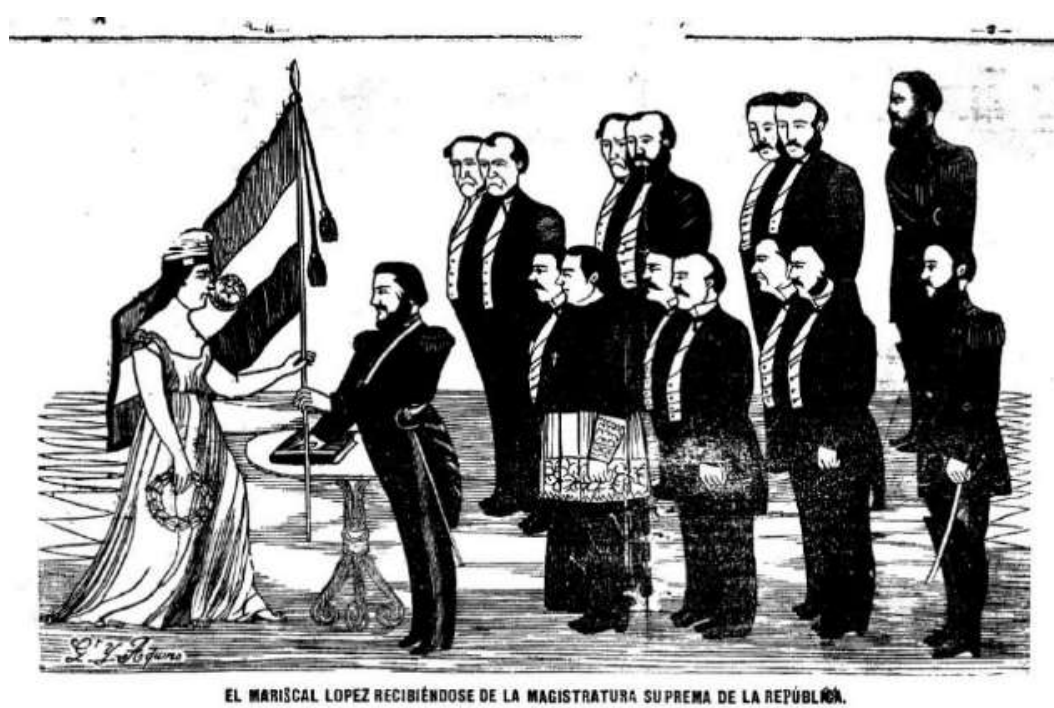

«El Mariscal López recibiendo de la Magistratrua Suprema de la República», Cabichuí 47 (18 de octubre 1867): 2-3. centralidad en los grabados, ya sea estando sola o enfrentándose a los aliados. No obstante, esta lucha que lleva adelante tiene a su principal guerrero y líder: el Mariscal López. Resulta interesante cómo cambia el protagonismo de los personajes cuando el gobernante paraguayo irrumpe los grabados del Cabichuí. Si se observa la publicación del 18 de octubre de 1867 , se pueden apreciar la centralidad que adquiere su figura.

La imagen publicada es un homenaje por un nuevo aniversario de la asunción de López como presidente del Paraguay. En ella se puede apreciar al Mariscal recibiendo la bandera paraguaya de manos de la República, quien carga una corona de laureles. El mariscal se encuentra con su mano apoyada en la biblia, mientras es observado por la asamblea que lo nombró para ocupar la «Suprema Magistratura». La república no ocupa el centro de la composición, sino que se encuentra desplazada por la figura de mandatario. No obstante, su presencia es importante: el cargo de presidente que ocupa López es investido por la propia República del Paraguay, bajo la aceptación de la asamblea que soberanamente lo dispuso. El presidente paraguayo recibe de su República la bandera, legitimando su puesto, y otorgándole la representación del país.

El artículo que acompaña este grabado explica que hace más de dos años que el Paraguay está en guerra contra los aliados y que ha sabido salir victorioso en varias batallas gracias al valor de su pueblo. Pueblo que «... inspirado divinamente había alzado su voz soberana, y con ella colocó al frente de sus destinos al esclarecido Guerrero, al inmortal D. Francisco S. López, para ser, como hoy, su gloria, y su honor, su Padre y su Defensor». ${ }^{24}$ Y prosigue:

24 «16 de Octubre. 1862», Cabichuí 47 (18 de octubre 1867): 2. 
Vedle, cual ahora cinco años, recibiendo de manos de la Patria la enseña sacrosanta de la libertad e independencia nacional; vedle apoyar sus manos sobre el código de la verdad evangélica, e invocar al Dios de los destinos ante las aras de la Patria, prometiendo religiosamente salvar sus vitales intereses y sagrados derechos. ${ }^{25}$

Las palabras publicadas en el Cabichuí se enfocan en exaltar a López como la cabeza del pueblo paraguayo, representando los intereses nacionales. Desplaza a la propia República de la centralidad, siendo esta colocada como elemento legitimador de su posición. Esto podría entenderse en el marco de la fecha que se conmemora; sin embargo, las siguientes líneas del texto abren paso a otra interpretación:

Al festejar el quinto aniversario de la actual administración, nos hallamos en la más autorizada ocasión para retorcer a los hipócritas conquistadores, que han tenido la sarcástica sandez de decir que no traían la guerra al pueblo paraguayo, sino al Mariscal López.

¿Quién le ha elevado al mando Supremo? ¿Qué deberes se impuso al tomar las riendas de la Patria? ¿Los ha cumplido, o no conforme a la voluntad nacional? ¿Mediante quien el Paraguay no es a estas horas esclavo del Brasil? [...]

Sepan, pues, nuestros cobardes invasores, que el Pueblo paraguayo más que nunca se halla hoy contento e inseparablemente adherido al Mariscal López, para con quien arde en amor y simpatías, con el más hondo reconocimiento de una eterna gratitud. ${ }^{26}$

Uno de los argumentos esgrimido por los aliados era que la guerra se hacía contra la tiranía de López y no contra el pueblo paraguayo. Es en relación con esto que el Cabichuí puntualiza sobre la legitimidad del Mariscal como representante de su Nación; una guerra contra López es una guerra contra el Paraguay, pues este fue electo por su pueblo como representante de la República. Mas allá de la conmemoración de un nuevo aniversario de la asunción presidencial, la ilustración se inserta en la propaganda contra la causa aliada. Como señala Johansson, existe una deificación de López, señalando la unión entre el pueblo - animalizado de forma positiva en el león- y su conductor (2014). La República es representada como elemento legitimador de la presidencia de López. Es este último quien dirige la batalla en nombre de ella.

Este juego entre República y López puede ser visto en el grabado del número 22, de fecha 24 de julio de 1867, publicado como homenaje a un nuevo aniversario del nacimiento del gobernante paraguayo. Se representa al mariscal enfrentándose al ejército

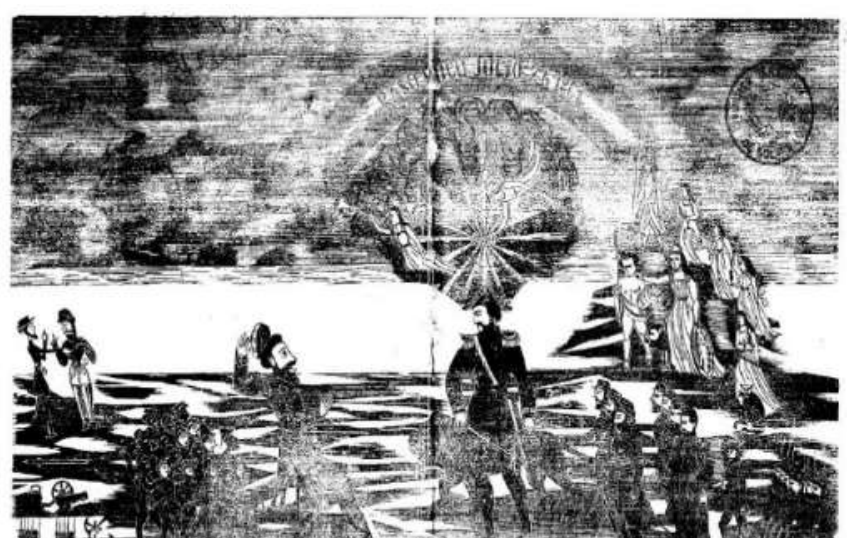

«El Mariscal López en frente de los enemigos de la Patria», Cabichuí 22 (24 de julio de 1867): 2-3

$25 \ll 16$ de Octubre. 1862» 2.
$26 \ll 16$ de Octubre. $1862 » 2$. 
aliado, en compañía del león. Pedro II se muestra atemorizado, mientras se le cae su corona; detrás, los soldados aliados - representados algunos con tez negra y otros con rostros blancos-, igual de atemorizados que el monarca, emprenden la retirada. En el fondo se puede observar a Mitre y a Flores en lo que parece una discusión, o simplemente sin entender lo que sucede.

En el otro extremo se representa al ejército paraguayo detrás de López y el león, cargando sus armas, y en armoniosa formación. ${ }^{27}$ Encima de estos, descendiendo del cielo, se observa a una república, junto con otro león, sosteniendo el escudo de Paraguay. Esta se encuentra acompañada de distintas representaciones femeninas de la justicia balanza-, la abundancia - cuerno de la abundancia-, la razón -llama en la palma de la mano-, y una Minerva - como símbolo de la guerra y la sabiduría-. A su vez aparece una figura masculina, también con un cuerno de la abundancia y una lanza, posiblemente señalizando la prosperidad o el progreso. Sobrevolando a López, se representan dos figuras aladas con atributos a la victoria - acompañadas de la leyenda «Paso Pucú Julio 24 1867»-, de las cuales una de ellas coloca una corona de laurel al mariscal. Explica Amigo con respecto a este grabado:

La imagen responde a la tradición del héroe republicano, a esos ciudadanos virtuosos sacrificados por la Libertad; sin embargo, esta inclusión desvía el sentido del conjunto alegórico clásico asociando República con Caudillo. [...] El conocimiento alegórico del dibujante, conocedor de las iconologías de Cesare Ripa y de Gravelot y Cochin, es sorprendente para este grabado de factura popular (25-26).

Este xilograbado repite el mismo patrón en la representación conjunta de López y la república. Esta última se encuentra a un lado, y es el presidente quien ocupa la centralidad; la República, y sus acompañantes, se encuentran como elementos que legitiman y simbolizan las virtudes de López como conductor del país y el ejército. Las figuras que sobrevuelan y descienden del cielo son utilizadas como forma de dar cuenta de los atributos del mariscal. En este sentido, la república es colocada tanto como símbolo de los valores republicanos de dicho general, como legitimadora de la posición que ocupa. Su presencia certifica que las acciones de López están en consonancia con los intereses de

\footnotetext{
${ }^{27}$ La composición de este grabado también reafirma la contraposición entre república y civilización y entre monarquía y barbarie, como destaca Johansson (2012b). Si se observa existe una clara oposición entre un extremo y otro de la imagen: por un lado, los aliados se encuentran en una situación de caos, de retirada, de desorganización, o de anarquía; en el lado paraguayo, la formación de las tropas, las figuras que descienden el cielo, y el propio mariscal, se encuentran en orden, en armonía, y marchando contra el enemigo. En sintonía con el trabajo de Amigo (2016), esta contraposición entre lo dionisíaco del enemigo, y lo apolíneo del Ejército paraguayo, muestra la construcción de dos bandos irreconciliables. Así, los valores contrapuestos entre civilización y barbarie, entre libertad y esclavitud, entre ciudadanos y súbditos, entre López y Pedro II, cargan a la guerra de un significado de lucha entre república y monarquía.
} 
ella, y en el día de su cumpleaños se manifiesta para legitimarlo. El artículo correspondiente señala que en este día:

La Patria se levanta a saludarlo, y bendecirlo con el entusiasmo que inspiran los grandes acontecimientos. [...]

¡Oh! El tiempo en su curso infinito viene a marcar este día un inmortal recuerdo de la aparición de una estrella en el horizonte de la Patria, es el glorioso cumpleaños del Exmo. Sor. Mariscal Ciudadano Francisco S. López. ${ }^{28}$

Más allá de la celebración del cumpleaños del mariscal, se busca exaltar la figura del presidente como representante de los intereses del Paraguay. La república que baja a saludarlo en su cumpleaños, es la misma que lo invistió como el primer ciudadano, legitimando su actuar en la batalla. Aun más, quienes la acompañan en el saludo son los valores que López «encarna». El discurso del Cabichuí, como publicación oficial de un Estado en guerra, legitima al presidente, y busca construir una comunidad entre el primer mandatario, el pueblo, y la institución republicana (Johansson 2014).

Esa asociación de república y caudillo que señala Amigo tiene una variante distinta para el caso de El Centinela, al momento de abordar los mismos acontecimientos a que refieren estos dos últimos grabados. El 24 de julio, en su número 14, el periódico publicado en Asunción homenajea al mariscal con el siguiente grabado.

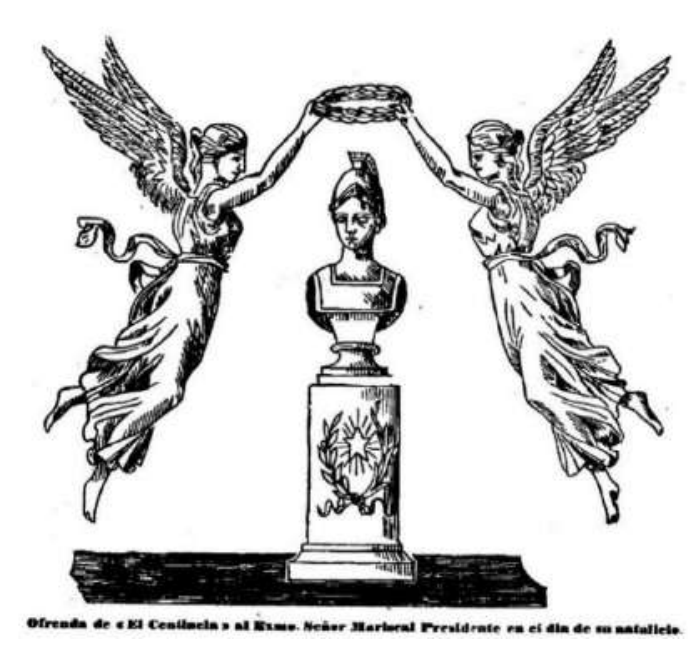

«Ofrenda de El Centinela al Exmo Señor Mariscal Presidente en el día de su natalicio», El Centinela 14 (24 de julio de 1867): 3 .

A diferencia del Cabichuí, el grabado no representa al mariscal, sino que presenta un busto de Minerva sobre un pedestal con los símbolos del escudo paraguayo. Junto a este, dos ángeles se disponen a colocarle una corona. El artículo correspondiente describe la ilustración de la siguiente manera:

«El Centinela» viene también con su modesto contingente a componer el florón que los hijos del Paraguay ofrecen, felicitando a su predilecto Mariscal.

28 «24 de Julio», Cabichuí 22 (24 de julio de 1867): 1. 
La Patria y la Libertad, simbolizadas en esos dos ángeles, ofrecen la corona de la gloria al genio de la guerra.

Esta es la sencilla alegoría con que «El Centinela» saluda el natalicio del Jefe Supremo del Estado.

Esta es la cordial y expresiva ofrenda del soldado que os admira, Padre y Libertador del Paraguay. 29

Resulta interesante la diferencia entre ambos periódicos para homenajear a López. En el Cabichuí su figura es representada y ocupa la centralidad de la imagen; es acompañada de una gran cantidad de alegorías y la presencia de la República se encuentra a un lado del mariscal. En cambio, El Centinela opta por una representación de Minerva como símbolo del «genio de la guerra», en referencia a López; imagen acompañada por dos ángeles, «La Patria» $\mathrm{y}$ «La Libertad», quienes ofrendan una corona de laurel. Podría decirse que existe una asociación explícita entre el caudillo y la república en lucha: no solo es el homenaje al mariscal en su cumpleaños, es un homenaje a quien encarna a la nación en el campo de batalla. La elección del busto de Minerva para homenajear a López transfiere sus virtudes guerreras e intelectuales, así como su papel de protectora de Roma -cuna del régimen republicano-, al gobernante de la República paraguaya.

Similar juego entre la república y su conductor ocurre cuando El Centinela homenajea un nuevo aniversario de la asunción de López al poder, el 17 de octubre de 1867, en el número 26. Haciendo referencia al mismo hecho que representaba el Cabichuí, su par publicado en la capital opta por una alegoría sin la presencia del mariscal. En este caso se representa una república que sigue el modelo europeo francés de Marianne; sostiene una lanza y porta una corona de olivos en su otra mano. A su alrededor distintas coronas señalan virtudes, acontecimientos y logros del Paraguay: «El Congreso Nacional de Paraguay», «Industria y Progreso», «Dignidad Nacional», «Ferrocarril», «16 de Octubre de 1862», «Telégrafo», «Libertad y Laureles», y

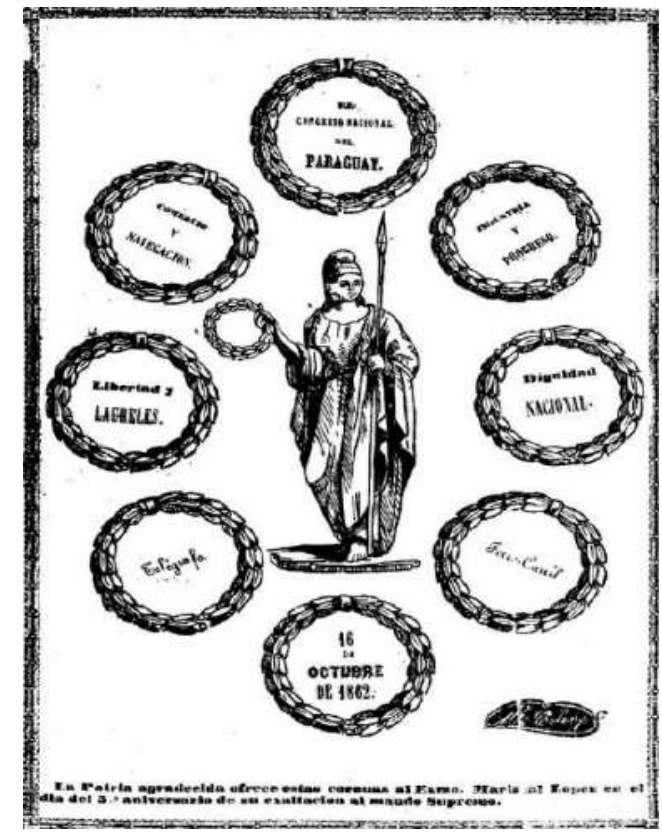

«La Patria agradecida ofrece estas coronas al Exmo. Mariscal López en el día del $5 .^{\circ}$ aniversario de su exaltación al mando Supremo», El Centinela 26 (17 de octubre de 1867): 3 . «Comercio y Navegación».

Nuevamente El Centinela se aparta de la forma de referir a la toma de gobierno de

29 «24 de Julio», El Centinela (24 de julio de 1867): 1. 
López, en comparación con el Cabichuí. No se representa al gobernante, sino que se opta por una república que da cuenta de los logros bajo su presidencia. El título del grabado deja en claro que el homenaje es hacia el mariscal, estableciendo una asociación de su figura con la república en sí; en otras palabras, se sustituye la figura del gobernante por una alegoría republicana que reivindica su gestión.

Estas diferencias entre Cabichuí y El Centinela, para referirse a los mismos acontecimientos, da cuenta de algunos aspectos interesantes. Ambos comparten alegorías similares, indicando un conocimiento común en torno a la iconografía republicana y siguiendo un discurso similar: Paraguay y Solano López son los representantes de las virtudes republicanas en un continente sudamericano, amenazado por la monarquía brasilera. La causa paraguaya es la causa republicana.

No obstante, en los homenajes dispensados a López por el 24 de julio y el 16 de octubre, el Cabichuí elige representarlo, desplazando a la República de la centralidad. En cambio, El Centinela prefiere apelar a la alegoría republicana para celebrar al mariscal, pero sin ponerlo en escena. Amigo (2016) señala que esta diferencia podría radicar en los lugares de publicación de ambos periódicos: el Cabichuí se imprimía en Paso Pucú, en el frente de batalla, teniendo una relación más estrecha con la tropa; en cambio, El Centinela se publicaba en Asunción, capital donde la cultura letrada se desarrolló siguiendo el modelo europeo, bajo el amparo de los gobiernos de los López. En este sentido, Johansson (2016) destaca el papel de los «soldados artistas»,30 dando cuenta de la participación del arquitecto italiano, Alessandro Ravizza, al frente de El Centinela, acompañado de sus colaboradores -y principiantes en la tarea del grabado- Juan José Benítez y Manuel L. Colunga. Por otro lado, El Cabichuí no contaba con un artista formado como Ravizza, sino con soldados que fungieron como grabadores -Saturio Ríos, Francisco Velasco, G. I. Aquino, Gregorio Cáceres, Juan Vargas, entro otros (Caballero Campos y Ferreira Segovia 2006)-. La autora indica que esto es puntualizado por los propios periódicos, siendo motivo de orgullo la destreza de estos soldados en el uso del buril y la madera. ${ }^{31}$

Mas allá de estos detalles, las diferencias en las alegorías republicanas señaladas dan cuenta de una iconografía compartida, que es utilizada de distinta forma para

\footnotetext{
30 En torno a los grabadores ver el trabajo de Josefina Pla, El grabado en el Paraguay (1962).

${ }^{31}$ Es interesante la perspectiva que aporta Johansson (2014b) sobre la relación entre la cercanía de estos «soldados artistas» $\mathrm{y}$ «soldados redactores» con los acontecimientos del enfrentamiento. Explica la autora que la prensa de trinchera se interesó por una práctica periodística cuya veracidad radica en la cercanía con los campos de batalla: «A través de este nuevo personaje-símbolo del «escritor soldado», se ponía de manifiesto que la cercanía al campo de batalla era considerada una garantía de veracidad en la información periodística» (100).
} 
transmitir un mismo mensaje a favor de la causa paraguaya. En otras palabras, al comparar el Cabichuí y El Centinela, es posible constatar un universo iconográfico amplio, capaz de ser puesto en práctica de distintas formas. Así, ante los mismos acontecimientos y siguiendo un mismo discurso, el concepto República es utilizado y representado con variantes según el periódico.

\section{Consideraciones finales}

A lo largo de este análisis se ha observado cómo las distintas ilustraciones y textos construyen un discurso propagandístico a favor de la causa paraguaya en él que se presentan dos bandos contrapuestos, donde cada uno representa no solo a los países implicados, sino también a valores universales en disputa. En un contexto de estancamiento del conflicto, resultaba importante mantener a la tropa motivada y recordar quien era el enemigo y por qué se estaba luchando. Este discurso también era un mensaje hacia el exterior, como se observa en las distintas denuncias y llamados al resto de países americanos.

Tomando los postulados de Mitchell (2017), las representaciones del concepto República puede ser leída como anhelo por establecer un discurso cohesionador, en un contexto bélico. Como señala Johansson (2012), los periódicos, con sus grabados, tuvieron un papel pedagógico, disciplinador y constructor de rasgos identitarios (119). En estas operaciones propagandísticas también hay un papel de constructor, reafirmador y difusor de conceptos políticos. En esta lógica, el concepto de república ocupa un lugar importante; las distintas formas en que se representa - asociado al de patria o nacióntienen una fuerte influencia de la tradición francesa -emulando la figura de Marianne. A su vez, se observan ciertos elementos que refieren al espacio americano: la fauna, la flora, y la propia tradición y lengua guaraní, por un lado; la idea de una América del Sur republicana, por otro. En relación con lo último, el concepto en cuestión es señalado como base argumentativa para deslegitimar la posición aliada en el conflicto.

De esta manera, como señala Johansson (2014), se contrapone ambos bandos, estableciendo a la Triple Alianza, con Pedro II como su principal artífice, como representantes del imperialismo, la esclavitud, la barbarie, y la monarquía; los grabados donde los aliados - desde la tropa hasta sus gobernantes - son racializados, animalizados o vampirizados, buscan ridiculizar e ilustrar estos valores negativos que defiende el invasor, y amenaza al Paraguay. Por otro lado, el Paraguay es señalado como bastión de la libertad, la civilización, el sistema republicano, y la unión de una América republicana. De esta manera, el concepto de República resulta central para distanciarse de los aliados, 
aglutinar a la población contra un enemigo identificable, y apelar a la unión con los demás países de la región.

El enemigo principal que se construye es el Imperio brasilero y en oposición a este, el discurso por la causa paraguaya da forma a su yo. Como señala Johansson (2012b), se contrapone la esclavitud en Brasil con la libertad de los ciudadanos paraguayos; el sistema monárquico brasilero con el gobierno republicano del Paraguay, la barbarie del gobierno de Pedro II con el progreso y la civilización del país del mariscal López. Las ilustraciones y los artículos van estableciendo distintos conceptos para cada bando, cargando a la batalla de un significado más allá de un mero enfrentamiento bélico. La causa paraguaya no es solamente de los ciudadanos paraguayos; el Paraguay está defendiendo la soberanía, la civilización, la libertad y la independencia de la América republicana, frente a las aspiraciones imperialista de una Monarquía bárbara y «esclavócrata».

De esta manera, las imágenes donde se representa el concepto de República, se insertan en el discurso propagandístico del gobierno paraguayo. Los grabados analizados, acompañado de sus artículos correspondientes, dan cuenta de una iconografía que ilustra los conceptos políticos que argumentan la posición del Paraguay en la disputa.

A pesar de la prédica de estos periódicos de trincheras, la guerra tuvo un resultado desfavorable para el Paraguay. Este fue arrasado por las fuerzas aliadas y López asesinado en Cerro Corá el $1 .^{\circ}$ de marzo de 1870. Sin embargo, es interesante observar cómo el concepto de república resultó clave en la propaganda esgrimida en el frente paraguayo y en el exterior. Su existencia da cuenta de un universo conceptual e iconográfico que fue puesto al servicio de una de las guerras más cruentas del siglo XIX en el Río de la Plata.

\section{Obras citadas}

\subsection{Fuentes}

Cabichuí, [Paso Pucú], may. 27, 1867: 5, Imprenta Nacional.

Cabichuí, [Paso Pucú], jun. 10, 1867: 9, Imprenta Nacional.

Cabichuí, [Paso Pucú], jul. 24, 1867: 22, Imprenta Nacional.

Cabichuí, [Paso Pucú], jul. 25, 1867: 22, Imprenta Nacional.

Cabichuí, [Paso Pucú], ago. 5, 1867: 26, Imprenta Nacional.

Cabichuí, [Paso Pucú], oct. 18, 1867: 44, Imprenta Nacional.

Cabichuí, [Paso Pucú], dic. 16, 1867: 65, Imprenta Nacional.

El Centinela, [Asunción], jul. 24, 1867: 14, Imprenta Nacional.

El Centinela, [Asunción], oct. 17, 1867: 26, Imprenta Nacional. 


\subsection{Bibliografía}

Acree, William. La lectura cotidiana. Cultura impresa e identidad coelctiva en el Río de la Plata, 1780-1910. Buenos Aires: Prometeo Libros, 2013.

Amigo, Roberto. «La alegoría republicana en las trincheras. Una introducción a Cabichuí». Novapolis 10 (2016): 15-29.

Anderson, Benedict. Comunidades imaginadas. Reflexiones sobre el origen y la difusión del nacionalismo. Ciudad de México: Fondo de Cultura Económica, 1993.

Brezzo, Liliana y Victoria Baratta. «La imagen de Argentina en el Paraguay». La Argentina vista por sus vecinos. Identidades y alteridades nacionales en el Cono Sur. Ed. Paulo Cavaleri. Buenos Aires: Torre de Hércules, 2018. Web. 2 de junio de 2021. <https://repositorio.uca.edu.ar/handle/123456789/9312>.

Burke, Peter. Visto y no visto. El uso de la imagen como documento histórico. Barcelona: Crítica, 2005.

Burucúa, José Emilio y Fabián Alejandro Campagne. «Mitos y simbologías nacionales en los países del Cono Sur.» Inventando la nación. Iberoamérica. Siglo XIX. Ed. Antonio Annino y François Xavier Guerra. Ciudad de México: Fondo de Cultura Económica, 2003. 433-474.

Burucúa, José Emilio y Fabían Alejandro Campagne. «Mitos y simbologías nacionales en los países del Cono Sur». Inventando la nación. Iberoamérica. Siglo XIX. Ed. Antonio Annino y François Xavier Guerra. Ciudad de México: Fondo de Cultura Económica, 2003. 433-474.

Caballero Campos, Herib y Carlos Gómez Florentín. "“Ciudadanos amantes de una buena causa": la campaña política de "El Semanario de Avisos y Conocimientos Útiles" durante la guerra contra la Triple Alianza. 1865-1868». Revista Eletrônica Historia em reflexão 11.22 (2017): 121-139. Web. 2 de junio de 2021. $<$ https://ojs.ufgd.edu.br/index.php/historiaemreflexao/article/view/7940/4265 $>$.

Caballero Campos, Herib y Cayetano Ferreira Segovia. «El periodismo de guerra en el Paraguay (1864-1870)». Nuevo Mundo Mundos Nuevos (2006). Web. 2 de junio de 2021. <https://journals.openedition.org/nuevomundo/1384>.

Capdevila, Luc. "O gênero da nação nas gravuras da imprensa de guerra paraguaia: Cabichuí e El Centinela, 1867-1868». ArtCultura 9.14 (2007): 9-21. Web. 2 de junio de 2021. <http://www.seer.ufu.br/index.php/artcultura/article/view/1447>.

-. Una guerra total: Paraguay, 1864-1870. Ensayo de historia del tiempo presente. Buenos Aires: SB, 2010.

Capellan de Miguel, Gonzálo. «Los momentos conceptuales. Una nueva herramienta para el estudio de la semántica histórica». Conceptos políticos, tiempo e Historia. Ed. Javier Fernández Sebastián y Gonzálo Capellán de Miguel. Santander: Universidad de Cantabria-McGraw-Hill Interamericana, 2013. 195-233.

Couchonnal Cancio, Ana Inés. Donde nací como tú. Perspectivas en torno a la articulación de un sujeto político en Paraguay. Asunción: Tiempo de Historia, 2017.

Di Meglio, Gabriel. «República/ Argentina-Río de la Plata». Fernández Sebastián, Javier. Diccionario político y social del mundo iberoamericano. Madrid: Iberconceptos- 
Fundación Carolina-Sociedad Estatal de Conmemoraciones Culturales-Centro de Estudios Políticos y Constitucionales, 2009. 1270-1281.

Fernández Sebastián, Javier. «El enfoque de una historia de conceptos y su aplicación al mundo iberoamericano». Caetano, Gerardo. Historia conceptual. Voces y conceptos de la política oriantal (1750-1870). Montevideo: Ediciones de la Banda Oriental, 2014. 11-27.

Ferro, Gabo. Barbarie y civilización. Sangre, monstruos y vampiros durante el segundo gobierno de Rosas. Buenos Aires: Editorial Marea, 2008.

Huner, Michael Kenneth. «Toikove Nane Retã!Republican Nationalism at the Battlefield Crossings of Print and Speech in Wartime Paraguay, 1867-1868». Acree, William y Juan Carlos González Espitia. Building Nineteenth-Century Latin America. ReRooted Cultures, Identities, and Nations. Nashville: Vanderbilt University Press, 2009. 79-97.

Islas, Ariadna y Ernesto Beretta. «Del neoclasicismo ítalo-francés a las "repúblicas criollas" ». Segundo Congreso de la Asociación Uruguay de Historiadores (AUDHI). Montevideo, junio de 2019.

Johansson, María Lucrecia. «Inspiraciones bajo el estampido del cañón. Tensiones en torno a la escritura de la prensa en los periódicos de trinchera paraguayos (186769)». Folia Histórica del Nordeste 20 (2012): 117-138.

-. «Paraguay contra el monstruo antirrepublicano. El discurso periodístico paraguayo durante la Guerra de la Triple Alianza (1864-1870)». Historia Crítica 47 (2012b): 71-92.

—. «La alianza proclamó guerra y esclavitud a la civilización». Anima II.3 (2012c): 45-56.

—. «Construyendo la nación a través de las imágenes. Los grabados de movilización bélica en la prensa de guerra paraguaya (1867-1868)». Revista Paraguaya de Sociología 51.146 (2014): 89-104.

-. «La noble propaganda de la libertad. Estrategias propagandísticas de la prensa paraguaya durante la Guerra de la Triple Alianza (1864-1870)». Tinkuy. Boletín de investigación y debate. Prensa temprana, comunidades e identidad 21 (2014b): 95-112.

—. «Dibujando la nación desdibujando al enemigo. Imágenes de movilización bélica en la prensa de guerra paraguaya, 1867-1868». Jahrbuch für Geschichte Lateinamerikas (2016): 211-226.

-. La gran máquina de publicidad. Redes transnacionales e intercambios periodísticos durante la guerra de la Triple Alianza (1864-1870). Sevilla: Universidad Internacional de Andalucía, 2017.

Maestri, Mário. A guerra no papel. História e Historiografia da Guerra no Paraguai (1864-1870). Passo Fundo: FCM Editora, 2013.

Mitchell, W. J. T. ¿Qué quieren las imágenes? Vitoria: Sans Soleil Ediciones, 2017.

Pla, Josefina. El grabado en el Paraguay. Asunción: Alcor, 1962.

Silveira, Mauro César. La batalla en los periódicos. La caricatura como arma en la guerra contra el Paraguay. Asunción: Arandura Editorial, 2017.

Sosa Vota, María Silvina. «Rivalidades históricas: la imagen de Brasil en la prensa ilustrada porteña a finales del siglo XIX». Revista Eletrônica da ANPHLAC 22 (2017): 118-146. 
Valero, Perla. «Imágenes desde la esclavocracia brasileña. El discurso civilización/barbarie durante la Guerra del Paraguay». Cuaderno del CEL II.3 (2017): 193-208. 